\title{
Existence Of Licence, Infrastructure, And Energy Recources In Increasing Small Business Capacity In Sidoarjo District In The New Normal 4.0
}

\author{
I Putu Artaya ${ }^{1}$, Tubagus Purworusmiardi ${ }^{2}$, I Gede Arimbawa ${ }^{3}$, Made Kamisutara ${ }^{4}$ \\ University Narotama Surabaya \\ 1putu.artaya@narotama.ac.id 2tubagus.purworusmiardi@narotama.ac.id \\ 33gede.arimbawa@narotama.ac.id made.kamisutara@narotama.ac.id
}

\begin{abstract}
This research was conducted in Sidoarjo Regency which has a lot of potential to grow and develop small businesses in three regions that is Krembung, Jabon, and Tulangan. The problem is one of the potential growth and development of small business activities in these three districts which has been supported by increased speed in business licensing, adequate infrastructure and the availability of renewable energy sources (gas) for smooth running and assistance for small businesses in the regions. To prove this, this research requires an increase in licensing, provision and improvement of infrastructure, and energy resources that can support its development activities for small business growth in the new normal 4.0. Of the three regions that were the object of research, at random there were 173 small business owners who were subjected to data collection in the field. As a basis for making decisions in an effort to overcome the above problems, the method used in this study is Crosstabs analysis, to test and determine whether there is a linearity between the potential for small business development with the availability of licensing management facilities, infrastructure provision, and supply of energy resources. the main pillar of the smooth running of small businesses in developing business activities, distribution and marketing of their products. From the test results, it turns out that the three facilities mentioned above, all have a linear relationship with the growth of small businesses in the three districts.
\end{abstract}

Keywords: Small business facilities, business growth, Crosstabs test.

\section{INTRODUCTION}

Sidoarjo Regency is an area located south of the Madura Strait, very rich in fishery products. Two of them are abundant, Shrimp and Crab. Furthermore, this area then has core business in the fisheries, industry and services sectors. Sidoarjo Regency has even become one of the economic backers of East Java Province. However, in addition to natural resources, Sidoarjo Regency is also blessed with extraordinary human resources. The regency, which consists of 18 districts and 353 sub-districts, has many small businesses spread across various regions. The number of Micro, Small and Medium Enterprises in Sidoarjo Regency is predicted to reach 134 thousand. This area is referred to as the City of SMEs. The products produced by MSMEs in Sidoarjo are already famous for their quality that is not in doubt. Many international trade brands are known to order products specifically from the Sidoarjo Regency SMEs. Previously, the number of MSMEs in Sidoarjo was around 160 thousand MSMEs, then this year it increased to 206 thousand MSMEs. While the number of large companies in Sidoarjo also increased from 1,600 to 2,000 . With such conditions, it is necessary to provide a support for the growth and development of small businesses in the Sidoarjo region, that is the improvement of licensing procedures that are getting faster, improvement and provision of better infrastructure, and the availability of energy resources in this case is natural gas as one of the one important 
component for the life of the small business industry, especially the small home industry which is growing rapidly.

Based on Perwitasari's research (2016) on integrated licensing services in Sidoarjo, the results of licensing models in Sidoarjo have been classified as good and conducted online, the priority aspect in licensing is speed, accuracy, and reliability. On another occasion the research conducted by Berlin, Noor, Siswidiyanto et al (2010), said that to improve and restore the development of businesses in the Sidoarjo region, especially areas that had been affected by the Lapindo mud needed to improve and add infrastructure to support and restore the growth of small businesses in an effort to improve the economy of East Java in general so that small businesses in Sidoarjo again have good prospects in long-term. And the last of Kristiawati's research results (2011), the results of this study revealed that the Sidoarjo regency government through PT Petrogas Jatim Utama, must be able to provide natural gas resources that have affordable prices in an effort to improve the life of small businesses in the Wedoro and Ngingas Sidoarjo areas, so that the life and growth of small businesses in the region have good competitiveness with the availability of affordable energy resources.

From the results of the three studies above, all of them state that licensing, infrastructure provision, and energy resources, especially natural gas, are important aspects in supporting the growth and potential of developing small businesses in Sidoarjo Regency significantly. While the research conducted in 2020 is to test or measure the degree of linearity of the relationship between the potential growth of small businesses with guaranteed and reliable licensing services, the availability of good infrastructure, and the availability of adequate energy resources for the survival of small businesses in the future.

\section{LITERATURE REVIEW}

According to Hadi (2018), the service of making investment and business licenses in Sidoarjo, East Java, is integrated with the central government. Thus, the process of making permits can be monitored by the government in Jakarta. Sidoarjo became a pilot district to implement online permit-making services. The licensing process at the One-Stop Integrated Investment Service Office of Sidoarjo Regency has been integrated with the central government. The system serves the process of making permits quickly. This is as regulated in Government Regulation No. 24 of 2018, concerning government efforts to simplify business licensing and create a model of integrated licensing services that is fast and inexpensive, and provides certainty. With a one-door system, business licenses will be obtained by business people in less than an hour, provided the applicant has completed the required documents. The government also regulates the types, applicants, and issuance of business licenses, implementation of business licensing, sector-based business permit reforms, one-stop systems, institutions and funding incentives or disincentives for business licensing through one-stop services, problem solving and business barriers.

In the past three years, the Sidoarjo district government has continued to improve the licensing process. Innovation for the sake of innovation is done. Sidoarjo does not want the potential of the region to be a magnet for wasted investment. Moreover, investment in Sidoarjo has fallen sharply since the mud eruption in Porong Sidoarjo. 
All licensing processes in Sidoarjo are already online. Officers are even more rarely or almost never meet with the license applicant.

All licensing processes in Sidoarjo are already online. Officers are even more rarely or almost never meet with the license applicant. One-stop service has been implemented in Sidoarjo since August 2018, until now, there have been 2,200 permit applications. One way to advance business and trade activities in Sidoarjo district is by implementing licensing facilities through an online system so that it can be done effectively and efficiently, both for business people and investors.

\section{Benefits of Licensing}

According to Augustine (2015), one of the government's efforts to encourage the growth and development of Micro and Small and Medium Enterprises is to facilitate licensing for MSMEs throughout Indonesia. With the Presidential Regulation Number 98 of 2014 concerning Licensing for Micro, Small and Medium Enterprises, permits for MSMEs are only 1 sheet and can be issued in only 1 day by the district. MSMEs can get 4 benefits. First is the legality of the business, then the ease of getting capital because it is legal, then access to business assistance from the government, and the last is the opportunity to get empowerment assistance from the government.

The four main benefits obtained by MSME entrepreneurs by taking care of and having a license for their business are:

1. MSMEs have the certainty of trying that they are legal, so that in the implementation of business activities everything becomes clear, and the government is easier to monitor business activities, especially in an effort to improve communication and guidance for the business actors themselves.

2. Access to finance is facilitated, each business certainly has an interest in dealing with creditors in an effort to increase the amount of funds and capital if needed in an effort to expand the business, by having a permit, of course the government will easily provide access to these business actors.

3. Business actors have the opportunity to obtain assistance facilities. In long-term business activities, business actors need various types of training activities to provide insight, skills, information and business development opportunities. With the ownership of a business permit, of course this becomes easier in an effort to get facilities and guidance from the government.

4. Empowerment activities. Economic growth and market demand, which sometimes changes dynamically and rapidly, must be anticipated by every business actor. Through licensing, business actors will easily communicate and interact in getting all types of assistance and partnerships with external parties, including in this case the activities of empowering business actors on an ongoing basis. This includes efforts to build networks of fellow business people.

\section{Provision of Infrastructure Facilities}

In addition to the role and benefits of licensing for businesses, in developing a business in general, infrastructure facilities are also needed for the dynamics and mobility of the transportation products of each business actor when they market and distribute their products. Infrastructure facilities that have become the key to smooth operations of business activities include the availability of ports for goods distribution activities both in the country or locally and 
for export purposes. According to Kristiawati (2011), an airport is also needed for the distribution and marketing of products from small businesses that have special market potential, with the aim of transcontinental distribution. Adequate facilities will certainly greatly assist the business actors themselves in efforts to distribute their products as well as marketing activities abroad. Another condition that is no less important is to expedite the process of moving, goods or products in a city when the products are ready to be distributed is the availability of access to roads or other means that are faster and more efficient such as railroad transportation. With the availability of a good infrastructure network, the distribution of small business products to the port, to the airport, or to certain places to be smoother and saves time.

\section{Provision of Energy Resources}

One aspect to be able to develop a special business in Sidoarjo, of course, needs a business component that cannot be ignored. According to Biswas (2018) a very important industrial component in the growth of sourcing businesses is clean water, electricity and natural gas energy resources. The obligation of the government in this context is how to manage the energy resources needed to be fully allocated and need to support the potential of small businesses in the Sidoarjo region. Why this is important, there are several reasons:

1. Is a continuous business supporting component,

2. One component in the calculation of production costs for small business groups,

3. Attached and cannot be eliminated in the process of determining the selling price,

4. Has a high factor impact on business activities,

5. Unit price of energy resources is one element of competition, especially in the cost management process.

\section{Growth Potential of Small-Scale Enterprises in Sidoarjo District}

Sidoarjo City is one of the economic pillars in East Java, with its abundant natural products that can be seeded as one of the sectors in improving the economy. Aside from being one of the food barns in East Java, Sidoarjo is also rich in the potential of small businesses that are able to become one of the sources in increasing local revenue. With its potential, Sidoarjo has become a pilot in the development of small businesses in the province of East Java. The growth of small businesses that have the potential to support export products in East Java annually is around $4.8 \%$ (Sidoarjo in Figures, 2018). Until now there are around 168 thousand small businesses that continue to grow in Sidoarjo. To increase public interest in developing small businesses the government of Sidoarjo has done all kinds of services online, to cut down all forms of bureaucracy that are very inhibiting. So that in the future, the potential for growing small businesses is even greater. Sidoarjo Regency Government has tried to facilitate all the needs of small businesses so that all forms of obstacles can be overcome. Several local and international scale exhibitions have been held, the aim being that the original products of the city of Sidoarjo can be recognized more quickly and able to open up export market demand. Therefore, facilities to facilitate licensing, provision and expansion of infrastructure and supply of energy resources become the main focus in an effort to revive and increase opportunities for the growth of business actors in Sidoarjo district. The interests of business actors abroad such as Thailand, Japan, Malaysia, Vietnam and some business actors in the ASEAN region, often come directly to buy commodities in Sidoarjo Regency, especially raw materials and semi-finished products. This can be seen in the following graphic display: 


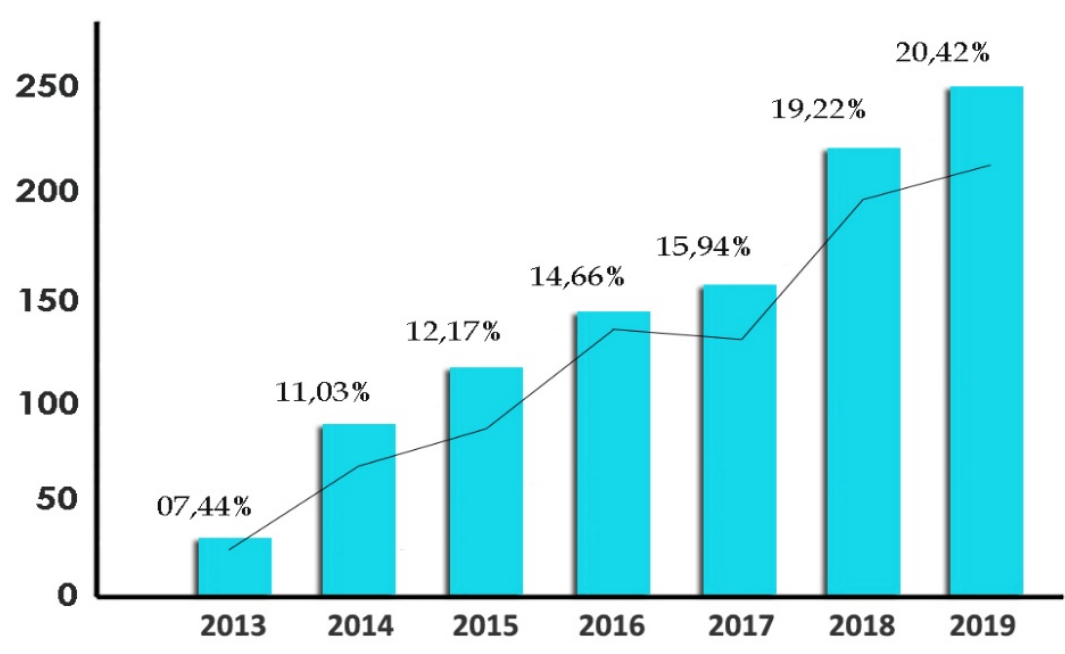

Figure 1. Growth in the Number of Small Business Actors in Sidoarjo Source: Sidoarjo in Figures 2019

\section{METHOD}

\section{Research Subjects and Samples}

The main subjects of this study are business people in three districts in the Sidoarjo region, such as Krembung, Jabon, and Tulangan. The total population of business owners in the three regions is 6500 business owners. However, the business owners sampled here are business owners who have just started their business for about a year. What is meant by business actors is a household business that has a small business in its place of residence. The total sample of research in three districts in the Sidoarjo region is 173 business owners.

\section{Data Collecting}

In an effort to obtain data, the main method conducted by researchers is through activities consisting of several aspects, that is:

1. Observation, this step is carried out to visit and see firsthand the condition of business activities carried out by business operators in their respective regions. Through this visit, it can be seen firsthand the actual conditions and picture in determining the research subjects.

2. Interview, a process to explore certain information that is carried out directly to business actors who have been selected as research samples. This interview is to get a picture of the actual conditions of the research study, that is licensing facilities, infrastructure provision, and energy resources, especially natural gas, which is indeed provided by the Sidoarjo district government to small businesses in developing businesses.

3. Tableization of the results of interviews and data collection, so that information on the results of interviews and data collection becomes more meaningful and can be used as analysis material then it needs to be presented in tabular form so that the meaning is easier to understand for study and discussion material. 


\section{Data Analysis}

To get results that meet the reality in the decision making process, one method that is relevant in the data analysis process is needed. The method used here for data analysis is the Crosstabs method (Santoso, 2010), which is to find whether there is a linear relationship between perceptions or attitudes of business actors with the efforts of the Sidoarjo district government, especially in providing important facilities to support the growth of business actors in Sidoarjo that is business licensing facilities, provision of infrastructure, and provision of energy resources. Through the Crosstabs test, it can be seen how much a linear relationship between the opinions of business actors with the efforts of the Sidoarjo district government has been carried out so far.

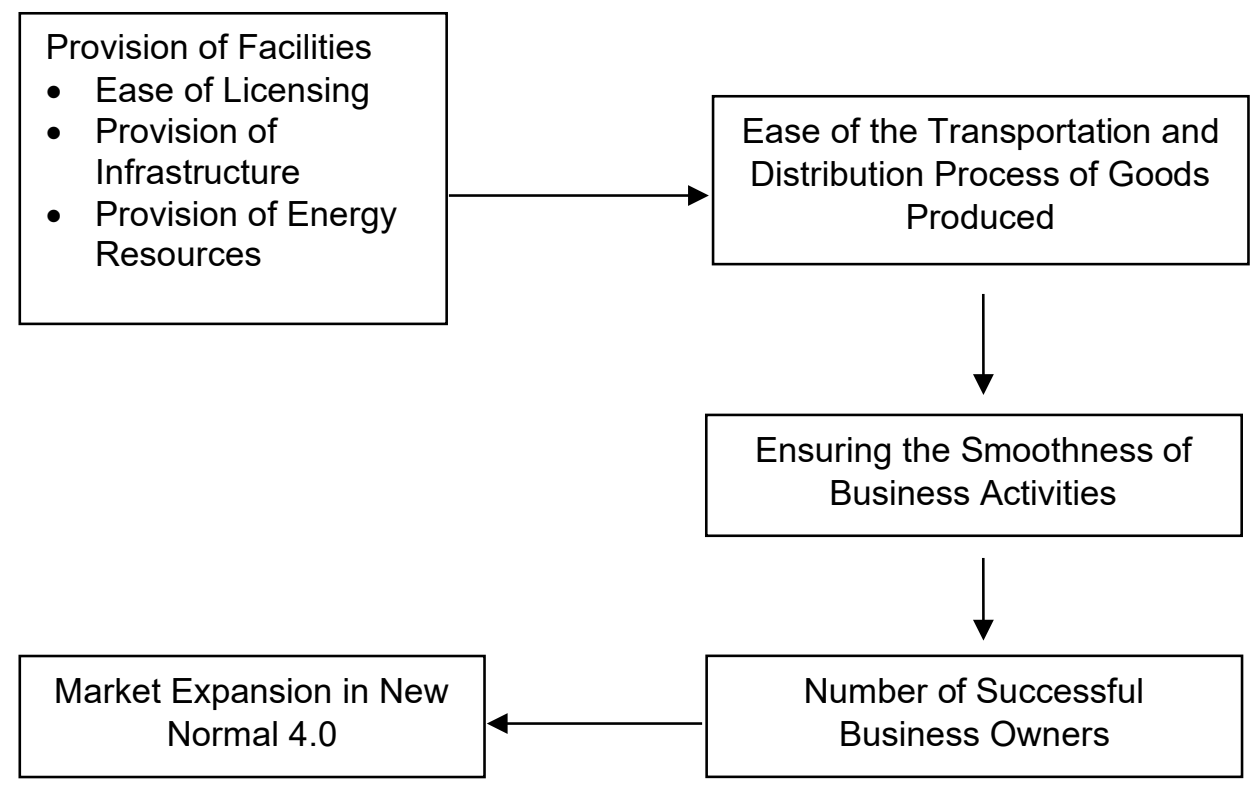

Figure 1. The Interrelation Between The Growth in The Number of Small Businesses and The Provision of Facilities

The picture above illustrates that the availability of all facilities from the local government, through the provision of all the facilities needed by businesses is a must. This condition is to provide confidence and an optimistic attitude for small businesses when starting a business or developing their own business to a wider market. Many local local products are successful in entering the export market because of the perseverance and courage of business owners to develop their businesses better. Provision of good facilities will trigger business owners to always try to find loopholes or export opportunities for their products, if this attitude can always be maintained well, the number of small business actors will continue to slowly increase because one business actor with other business actors always share information when they wants its products to enter the export market to other countries. 


\section{RESULT}

\section{Data Collection Results}

The results of interviews and observations in the field, from 173 business owners in the Krembung, Jabon, and Tulangan areas. Through observations and interviews that have been conducted with them, almost $52.3 \%$ of business owners still consider that the attention of the Sidoarjo city government has not been carried out optimally to them. The impact of this condition is that most business owners who want to export their superior products are still constrained in obtaining permission from the government, providing adequate and equitable infrastructure facilities that are appropriate for their business and ultimately providing cheap energy resources through government specific policies to small business owners who really need the attention of the local government in the city of Sidoarjo, are as follows:

Table 1. Results from the process of collecting data from interview activities in the Krembung area of Sidoarjo

\begin{tabular}{|l|c|c|c|c|}
\hline & \multicolumn{3}{|c|}{ Business Owner Response } & \multirow{2}{*}{ Amount } \\
\cline { 2 - 5 } & Success & $\begin{array}{c}\text { Not Completely } \\
\text { Successful }\end{array}$ & Unsuccessful & \\
\hline Licensing Services & 10 & 4 & 7 & 21 \\
\hline Provision of Infrastructure & 11 & 8 & 7 & 26 \\
\hline $\begin{array}{l}\text { Provision of Energy } \\
\text { Resources }\end{array}$ & 2 & 8 & 1 & 11 \\
\hline \multicolumn{1}{|c|}{ Amount } & 23 & 20 & 15 & 58 \\
\hline
\end{tabular}

Based on the data display in table 1 above, it can be described descriptively that business owners in the Krembung region, $32.7 \%$ stated that licensing services, infrastructure provision, and the availability of energy sources declared successful, this means that all the facilities they have enjoyed so far in connection with the business activities they do there are benefits. While $27.6 \%$ stated that the facilities provided by the Sidoarjo government had not been felt to the maximum by them, meaning that there were still obstacles when they enjoyed the three facilities in the process of developing their business. And the remaining $15.5 \%$ have never felt the benefits of the facilities available in connection with their business activities. This means that this last category is a group of business people who have not yet benefited from the service facilities that should have been intended for them. The reason could be due to certain factors.

Table 2. Results of the process of collecting data from interview activities in Jabon area of Sidoarjo

\begin{tabular}{|l|c|c|c|c|}
\hline & \multicolumn{3}{|c|}{ Business Owner Response } & \multirow{2}{*}{ Amount } \\
\cline { 2 - 5 } & Success & $\begin{array}{c}\text { Not Completely } \\
\text { Successful }\end{array}$ & Unsuccessful & \\
\hline Licensing Services & 18 & 4 & 2 & 24 \\
\hline Provision of Infrastructure & 14 & 3 & 2 & 19 \\
\hline $\begin{array}{l}\text { Provision of Energy } \\
\text { Resources }\end{array}$ & 3 & 9 & 4 & 16 \\
\hline \multicolumn{1}{|c|}{ Amount } & 35 & 16 & 8 & 59 \\
\hline
\end{tabular}


Based on the data display in table 2 above, it can be explained descriptively that business operators in Krembung area, 59.3\%, stated that success in licensing services, infrastructure provision, and availability of energy sources means that they feel that they are enjoying all the facilities, so far in connection with the business activities they carry out. While $27.1 \%$ stated that the facilities provided by the Sidoarjo government were not fully felt by them, which meant there were still obstacles when they enjoyed the three facilities in their business development process. And the remaining $13.5 \%$ have never felt the benefits of the facilities available in connection with their business activities. This means that this last category is a group of entrepreneurs who have not yet benefited from the service facilities that should have been aimed at them. Means that if seen from the magnitude of the percentage, government services and efforts in Sidoarjo in the Jabon region are relatively successful in providing convenience for businesses.

The reaction or opinion of business owners regarding the fulfillment of licensing facilities, infrastructure, and the availability of energy resources for small businesses is very much needed, so it can clearly be seen how successful the Sidoarjo government is in meeting the absolute needs of small businesses when they need them. support to develop in an effort to advance their business in the long run. With this real condition, the Sidoarjo government can make improvements to meet the basic needs of small businesses in order to grow and compete.

Table 3. Results of the process of collecting data from interview activities in Tulangan area of Sidoarjo

\begin{tabular}{|l|c|c|c|c|}
\hline & \multicolumn{3}{|c|}{ Business Owner Response } & \multirow{2}{*}{ Amount } \\
\cline { 2 - 5 } & Success & $\begin{array}{c}\text { Not Completely } \\
\text { Successful }\end{array}$ & Unsuccessful & \\
\hline Licensing Services & 21 & 8 & 6 & 35 \\
\hline Provision of Infrastructure & 7 & 1 & 0 & 8 \\
\hline $\begin{array}{l}\text { Provision of Energy } \\
\text { Resources }\end{array}$ & 11 & 2 & 0 & 13 \\
\hline \multicolumn{1}{|c|}{ Amount } & 39 & 11 & 6 & 56 \\
\hline
\end{tabular}

Based on the data display in table 3 above, it can be explained descriptively that business operators in the Krembung District area, $69.6 \%$ stated that licensing services, infrastructure provision, and availability of energy sources have been successfully implemented which means that all the facilities they have enjoyed so far related to their business activities. While $19.64 \%$ stated that the facilities provided by the Sidoarjo government had not been felt to the maximum by them, meaning that there were still obstacles when they enjoyed the three facilities in the process of developing their business. And the remaining 10.7\% have never felt the benefits of the facilities available in connection with their business activities. This means that this last category is a group of business people who have not yet benefited from the service facilities that should have been intended for them. It means that when seen from the large percentage, government services and efforts in Sidoarjo Regency in Tulangan Sub-district are relatively successful in providing facilities for business people as a whole. 
Table 4. Results from the data collection process in three districts in Krembung, Jabon and Tulangan in Sidoarjo

\begin{tabular}{|l|c|c|c|c|}
\hline & \multicolumn{3}{|c|}{ Business Owner Response } & \multirow{2}{*}{ Amount } \\
\cline { 2 - 5 } & Success & $\begin{array}{c}\text { Not Completely } \\
\text { Successful }\end{array}$ & Unsuccessful & \\
\hline Licensing Services & 46 & 16 & 9 & 85 \\
\hline Provision of Infrastructure & 36 & 12 & 9 & 43 \\
\hline $\begin{array}{l}\text { Provision of Energy } \\
\text { Resources }\end{array}$ & 14 & 18 & 13 & 45 \\
\hline \multicolumn{1}{|c|}{ Amount } & 96 & 46 & 31 & 173 \\
\hline
\end{tabular}

Based on the data in table 4 above, it can be reviewed descriptively that business operators in the Krembung, Jabon, and Tulangan Subdistricts $55.49 \%$ stated that licensing services, infrastructure provision, and availability of energy sources are in line with the expectations of the business owner, meaning that all facilities that they have enjoyed so far in connection with their business activities being able to provide benefits. This means that the Sidoarjo government has succeeded in making efforts to increase and spur the growth of business potential in the three districts. While $26.58 \%$, stated that the facilities provided by the Sidoarjo government had not been felt to the maximum by business owners, meaning that they still had certain obstacles when they enjoyed or received services or provided facilities in the process of developing their business. And the remaining $17.9 \%$ of business owners in the three districts have never felt the benefits of the facilities available in connection with their business activities so far. This means that this might be due to the lack of socialization and the government's lack of responsiveness in serving business owners in responding to the form of service facilities that should be intended for them. If seen from the large percentage, government services and efforts in Sidoarjo, especially in three districts that is Krembung, Jabon, and Tulangan, are relatively successful in providing facilities for business people as a whole in the sub-districts. However, businesses run by the Sidoarjo government still have shortcomings in serving the business owner as a whole.

\section{DISCUSSION}

The next step that must be taken in connection with a research study is conducting a Crosstab test to be used as a basis for decision making and presenting information in measuring the linear relationship of business owners in the process of providing licensing facilities, infrastructure, and energy resources in three districts in the city of Sidoarjo. Results are presented below:

Table 5. Validation of Crosstabs Data Case Processing Summary

\begin{tabular}{|l|c|c|c|c|c|c|}
\hline \multirow{2}{*}{} & \multicolumn{3}{|c|}{ Cases } \\
\cline { 2 - 7 } & \multicolumn{2}{|c|}{ Valid } & \multicolumn{2}{c|}{ Missing } & \multicolumn{2}{c|}{ Total } \\
\cline { 2 - 7 } & $\mathrm{N}$ & Percent & $\mathrm{N}$ & Percent & $\mathrm{N}$ & Percent \\
\hline $\begin{array}{l}\text { Government_Sidoarjo } \\
\begin{array}{l}\text { Services * Business } \\
\text { Owner Response }\end{array}\end{array}$ & 173 & $100,0 \%$ & 0 &, $0 \%$ & 173 & $100,0 \%$ \\
\hline
\end{tabular}


Table 6. Results Description of Responses of Business Owners

Government_Sidoarjo Services * Business Owner Response Crosstabulation Count

\begin{tabular}{|ll|c|c|c|c|}
\hline & & \multicolumn{3}{|c|}{ Business Owner Responses } & \\
\cline { 3 - 5 } & & Success & $\begin{array}{c}\text { Not } \\
\text { Completely } \\
\text { Successful }\end{array}$ & Unsuccessful & \\
\hline Government & Licensing & 46 & 16 & 9 & Total \\
\hline Sidoarjo Services & Infrastructure & 36 & 12 & 9 & 43 \\
& Energy Resources & 14 & 18 & 13 & 45 \\
Total & 96 & 46 & 22 & 173 \\
\hline
\end{tabular}

From table 5 and table 6 it can be explained that in the Crosstabs analysis process none of the data was wasted. All data is $100 \%$ used in the testing process. The data display in table 6 is the descriptive output of the Crosstabs test in accordance with table 4 above. Table 6 above shows the composition of the response of business owners in the form of distribution of answers, between Success, Not Completely Successful, and Unsuccessful. To present the test results it can be seen in table 7 below:

Table 7. Crosstabs Test Results

Chi-Square Tests

\begin{tabular}{|l|r|r|r|}
\hline & \multicolumn{1}{|c|}{ Value } & df & \multicolumn{1}{|c|}{ Asymp. Sig. (2-sided) } \\
\hline Pearson Chi-Square & $3,774^{\mathrm{a}}$ & 3 &, 037 \\
Likelihood Ratio & 3,795 & 3 &, 045 \\
Linear-by-Linear &, 007 & 1 &, 170 \\
Association & 173 & & \\
N of Valid Cases & & & \\
\hline
\end{tabular}

a. 4 cells $(26,4 \%)$ have expected count less than 4 . The minimum expected count is 2,71 .

Based on the appearance of the Crosstabs test results in table 7 above, the hypothesis testing for decision making can be explained as follows:

1. Pearson Chi-Square value, especially the error rate (Asymp. Sig.) Is 0.037 and the value is far below $5 \%(0.05)$ meaning $\mathrm{Ho}$ is rejected and $\mathrm{Ha}$ is accepted, which means that government services in Sidoarjo district have a linear relationship with the attitudes and responses of business actors in three districts that is Krembung, Jabon and Tulangan. This means that the Sidoarjo Regency government service in providing permits, infrastructure and energy resources can and is able to trigger or enhance business development for business owners or MSMEs in Sidoarjo.

2. It can now be clearly seen that licensing facilities, infrastructure provision, and energy resources for the development of potential business actors in Sidoarjo Regency have a linear relationship. This means that the responses of the business actors above presented in table 1 , table 2, and table 3 in the three districts used as research subjects, are indeed justified. The response is linear or real. Although a small number of business operators still state that they have not met the expectations of the facilities provided by the Sidoarjo Regency Government, overall this has brought benefits in an effort to spur the growth of business activities in the Sidoarjo district. 


\section{CONCLUSION}

Based on the results of testing using the Croostabs method for the response of business actors to the provision of facilities in Sidoarjo Regency, it can be concluded that the small business activities carried out by business operators in three districts in Sidoarjo that is Krembung, Jabon, and Tulangan have been in line with the expectations of the business actors, because they are based on distribution respondents or business owner answers $62.33 \%$ had fulfilled their expectations in an effort to develop their business so far. Although there is a small proportion of business actors, that is $14.28 \%$ feel that the facilities provided by the Sidoarjo government have not met their expectations, it is natural, because every business actor must have technical obstacles in running and developing their business. This means that it can be decided that in the future the Sidoarjo government must make better efforts to provide licensing facilities, infrastructure and supply of energy resources for businesses in Sidoarjo so that their business activities can be assisted in developing business activities especially for business owners who have no experience adequate. Some corrective steps for problems that occur can be resolved by perfecting the online licensing system that has been implemented so far by adding service capacity by providing various additional menu options in the online system. This is an important step in efforts to broaden understanding for MSME owners by reaching them more broadly. Improve infrastructure facilities and supporting facilities in more focused ways such as the construction of toll roads, railways and equal transportation facilities to facilitate the smooth distribution of goods and support the delivery of goods for export to ports and airports. Improving energy distribution, especially natural gas, is better and more equitable by building new natural gas pipelines that are able to reach areas where business owners live, because natural gas is an alternative energy source that is still relatively inexpensive compared to the others. So that not only large companies can enjoy this energy source facility but are able to reach small business owners in the city of Sidoarjo, especially in the Krembung, Jabon, and Tulangan areas.

Acknowledgments: We are happy to express our gratitude to the research team who have worked well together, so that all activities and actions in the research process can be completed properly. We hope that in the future, we will continue to be successful in better cooperation in other researches.

Conflicts of Interest: There are no conflicts of interest in writing this article, both among fellow writers and to external institutions as research partners.

\section{REFERENCES}

Agus Suroso, Ade Irma Anggraeni, Andriyansah. (2017). Optimizing SMEs'Business Performance Through Human Capital Management. European Research Studies Journal. Volume XX, Issue 4B. pp. 588-599.

Agustian, Ary Ginanjar., (2001), Rahasia Sukses Membangun Kecerdasan Emosi Dan Spiritual, Penerbit Arga, Jakarta.

Agustinus, Michael. (2015). Manfaat Pelaku UKM Jika Memiliki Ijin Usaha. 01 Desember 2015. From https://finance.detik.com/berita-ekonomi-bisnis/d-3085080/ini-manfaat-pelaku-ukm-punya-izin-usaha.

Andi Munandar. (2016). The Strategy Development And Competitive Advantages Of Micro Small Medium Enterprise Business Institution Toward Regional Development. Jurnal Pemikiran dan Penelitian Administrasi Bisnis dan Kewirausahaan. 1(2). pp. 103-112.

Andrzej Skibiski, Monika Sipa. (2015). Sources of Innovation of Small Businesses: Polish Perspective. 22nd International Economic Conference - IECS 2015. Economic Prospects in the Context of Growing 
Global and Regional Interdependencies. IECS 2015. Procedia Economics and Finance. Vol. 27. pp. $429-437$.

Anwarul Islam, and Miajee, Rezaul Karim. (2018). Exploring E-Business in SMEs. International Journal of Small and Medium Enterprises. 1(1). Published by Centre for Research on Islamic Banking \& Finance and Business.

Artarina DA Samoedra, Deni Hermana, (2019), Sustainability, Competitive Advantage and Entrepreneurial Orientation in Indonesian Family Culinary Business Groups, International Journal of Innovation, Creativity and Change, 6(11), pp. 314-326.

Bakri, R., Data, U., \& Saputra, A. (2019). Marketing Research : The Application of Auto Sales Forecasting Software to Optimize Product Marketing Strategies. Journal of Applied Science, Engineering, Technology, and Education, 1(1). pp. 7-12, https://doi.org/10.35877/454RI.asci1124

Berlin, Noor, Siswidiyanto et al,. (2010). Pelaksanaan Pembangunan Infrastruktur Pada Lokasi Dampak Semburan Lumpur Lapindo Kecamatan Porong Kabupaten Sidoarjo. From https://media.neliti.com/media/publications/80910-ID-pelaksanaan-pembangunan-infrastrukturpa.pdf.

Biswas, Tirtha. Sachin Sharma. and Karthik Ganesan. (2018). Factors Influencing the Uptake of Energy Efficiency Initiatives by Indian MSMEs. Council on Energy, Environment and Water. New Delhi.

Christabel Divine Brownson. (2014). Does Constituent Of Entrepreneurial Culture Differ In Individuals?. International Journal of Small Business and Entrepreneurship Research. 2(2). pp.22-27.

Cinzia Vallone \& Barbara lannone. (2020). Innovation trough Tradition in Family Business, International Journal of Business and Management, 15(1). 2020, pp.157-165. doi:10.5539/ijbm.v15n1p157

Das, S., \& Mohiuddin, K. M. (2015). Motivational factors and the constraints of women entrepreneurship development in Bangladesh. International Journal of Information, Business and Management, 7(3), 377-396.

Dobbs, M. and Hamilton, R. (2007). Small business growth: recent evidence and new directions. International Journal of Entrepreneurial Behavior \& Research. 13(5). pp. 296-322. https://doi.org/10.1108/13552550710780885

Grabowski, W., \& Stawasz, E. (2017). The role of business consulting in creating knowledge and formulating a strategy of development in Polish micro-enterprises. Journal for East European Management Studies. 22(3). pp 374-396.

Hadi, Syaikhul. (2018). Sistem Pembuatan Izin Usaha di Sidoarjo Dipantau Pusat. 02 Agustus 2018. From http://jatim.metrotvnews.com/peristiwa/nbw7Z1Rb-sistem-pembuatan-izin-usaha-di-sidoarjodipantau-pusat.

Hammouri, M., (2019). Analysis Of The Stage Of E-Commerce Adoption By The Hotel Industry In North Cyprus And Factors That Might Prevent Its Adoption. International Journal of Small Business and Entrepreneurship Research. 7(4). pp.14-25.

Hanitahaiza Hairuddin. Nor Laila Md Noor. and Erne Suzila Kassim. (2012). Developing Therapy-Based IT Adoption Model for Microenterprises. Journal of Innovation Management in Small and Medium Enterprises. Volume 2012. DOI: 10.5171/2012.271072.

Harnanto, Adi. (2018). Geliat UMKM Sidoarjo. 26 Mei 2018. From https://keuangan.co/isi/judul/Geliat_UMKM_Sidoarjo.

Junita J. S., Aryusmar, (2019), Analysis Model of Development Functional Requirement Knowledge Management Cycle for Performance Business Competitiveness in Indonesia Small and Medium Scale Enterprises (SMEs), 23(4), December 2019, pp. 1-10.

Kristiawati, E. M., (2011). Implementasi Harga Jual Gas Bumi Melalui Pipa PT Petrogas Jatim Utama Untuk Konsumen Rumah Tangga Di Desa Ngingas Kecamatan Waru Kabupaten Sidoarjo. From https://jurnalmahasiswa.unesa.ac.id/index.php/publika/article/viewFile/11703/10970.

Kurniawan, Dian. (2017). UKM Sidoarjo Bakal Jadi Sasaran Program UMKM Go Online. 08 Nopember 2017. From https://www.liputan6.com/bisnis/read/3155874/206-ribu-ukm-sidoarjo-bakal-jadi-sasaranprogram-umkm-go-online.

Luzaan H., Natasha de K.,(2016), Generation Y Female Students' Motivation Towards Entrepreneurship, International Journal Of Business And Management Studies, 8(2). 2016. Pp. 50-65. ISSN: 1309-8047. 
Mendy, J. and Hack-Polay, D. Learning from failure. Journal of Small Business and Enterprise Development. 25(2). pp. 330-343. 2018. https://doi.org/10.1108/JSBED-11-2017-0332.

Natanya Meyer, Rita Klonaridis. (2020). The Identification of Female Entrepreneurs' Business Growth Factors: Evidence From South Africa, International Journal Of Business And Management Studies, 12(1), 2020 ISSN: 1309-8047.

Perwitasari, E. W,. (2016). Kualitas Pelayanan Paket Perizinan Online Pada Badan Pelayanan Perizinan Kabupaten Sidoarjo,

From http://jurnalmahasiswa.unesa.ac.id/index.php/publika/article/viewFile/16919/15375.

Santoso, Singgih, (2010), Statistik Parametrik, Solusi Bisnis Berbasis TI, Elek Media Komputindo, Gramedia Group, Jakarta.

Taufik, M. (2018). Proses Perijinan di Kabupaten Sidoarjo Dibuat Online. 22 Oktober 2018. From http://surabaya.tribunnews.com/2018/10/22/semua-proses-perijinan-di-kabupaten-sidoarjo-dibuatonline-ternyata-begini-tujuannya.

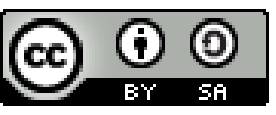

(C) 2020 by the authors. Submitted for possible open access publication under the terms and conditions of the Creative Commons Attribution (CC BY SA) license (https://creativecommons.org/licenses/by-sa/3.0/). 